\title{
Involvement of GABA-B receptors of the dorsal hippocampus in the inhibition of morphine-induced amnesia by morphine sensitization Mohammad-Reza Zarrindast*1,2, Vahid Hoghooghi ${ }^{1}$ and Ameneh Rezayof ${ }^{3}$
}

\author{
Address: ${ }^{1}$ Department of Pharmacology, School of Medicine, Tehran University of Medical Sciences, Tehran, Iran, ${ }^{2}$ School of Cognitive Science, \\ Institute for Studies in Theoretical Physics and Mathematics, Tehran, Iran and ${ }^{3}$ Department of Animal Biology, School of Biology, College of \\ Science, University of Tehran, Tehran, Iran \\ * Corresponding author
}

from International Society on Brain and Behaviour: 3rd International Congress on Brain and Behaviour

Thessaloniki, Greece. 28 November - 2 December 2007

Published: 17 April 2008

Annals of General Psychiatry 2008, 7(Suppl I):S207 doi:I0.I I86/I744-859X-7-SI-S207

This abstract is available from: http://www.annals-general-psychiatry.com/content/7/SI/S207

(c) 2008 Zarrindast et al.; licensee BioMed Central Ltd.

\section{Background}

Our previous studies show that pre-training administration of morphine induces amnesia [1] and this effect was significantly reduced in morphine-sensitized mice [2]. In the present study the role of GABA-B receptors of the dorsal hippocampus in the inhibition of morphine-induced amnesia by morphine sensitization were investigated in mice.

\section{Materials and methods}

A single-trial step-down passive avoidance task was used for the assessment of memory retention in adult male NMRI mice. Animals were bilaterally cannulated in the CA1 regions by stereotaxic instrument, and were allowed to recover 1-week before behavioral testing.

\section{Results}

Morphine-induced amnesia was reversed in morphinesensitized mice which had previously received once daily injections of morphine for 3 days. The inhibition of morphine-induced amnesia in animals that had previously received the 3-days morphine treatment was significantly decreased by once daily injections of the different doses of GABA-B receptor agonist, baclofen prior to s.c. injections of morphine. Amnesia induced by pre-training morphine had no significant change in mice which had previously received once daily injections of CGP35348 plus an ineffective dose of morphine for 3 days.

\section{Conclusions}

The present results indicate that GABA-B receptors of the dorsal hippocampus may play an important role in the inhibition of morphine-induced amnesia by morphine sensitization.

\section{References}

I. Zarrindast MR, Jafari-Sabet M, Rezayat M, Djahanguiri B, Rezayof A: Involvement of NMDA receptors in morphine state-dependent learning. Intern J Neuroscience 2006, 1 16:1-13.

2. Zarrindast MR, Rezay of A: Morphine state-dependent learning: sensitization and interactions with dopamine receptors. Eur J Pharmacol 2004, 497: 197-204. 